\title{
Effects of Gibberellic Acid on Germination of Papaya (Carica papaya L.) Seed
}

\author{
Oscar D. Ramirez ${ }^{1}$ \\ INTRODUCTION
}

The papaya (Carica papaya L.) is a well-known and popular fruit in many parts of the world. It is pleasing to taste both as fresh or preserved fruit and is popularly considered medicinal.

Papaya seed germination is rather irregular. Alonso-Olivé $(1)^{2}$ reported that the germination of the papaya seed usually starts from 2 to 3 weeks after planting and sometimes even later. This slow germination rate is a handicap in the production of this fruit. Since gibberellic acid has been used successfully (2) to accelerate seed germination of various other crops, studies were conducted to investigate the possibility of utilizing it in accelerating papaya seed germination.

This paper reports the results of the preliminary studies conducted at this Station using various concentrations of gibberellic acid to determine its effect on papaya seed germination.

\section{MATERIALS AND METHODS}

Seed were obtained from a red-flesh papaya fruit and treated (fig. 1) with a proprietary product (3) containing 0.88 percent of potassium gibberellate. The dosages used were $0,2.50,5.00,7.54$, and $10.00 \mathrm{mg}$. of the abovementioned product per $2 \mathrm{gm}$. of seed. Seed and chemical were shaken together in a glass jar so that the chemical would adhere to the seedcoat.

After treatment the seed were planted in flats in the greenhouse. A $5 \times 5$ Latin-square design was used and 15 seed were sown in each plot. Daily germination records were taken for a period of 31 days.

\section{RESULTS AND DISCUSSION}

EFFECT OF GIBBERELLIC ACID ON THE TIME OF GERMINATION

The results obtained as to the effect of gibberellic acid on the time of germination are presented in the following tabulation:

$\begin{array}{cc}\text { Dosage in milligram } & \text { Mean days for germination } \\ 0 & 17.98 \\ 2.50 & 19.15 \\ 5.00 & 17.34 \\ 7.54 & 18.53 \\ 10.00 & 17.66\end{array}$

${ }^{1}$ Assistant Plant Breeder, Agricultural Experiment Station, University of Puerto Rico, Río Piedras, P.R.

' Italic numbers in parentheses refer to Literature Cited, p. 190. 

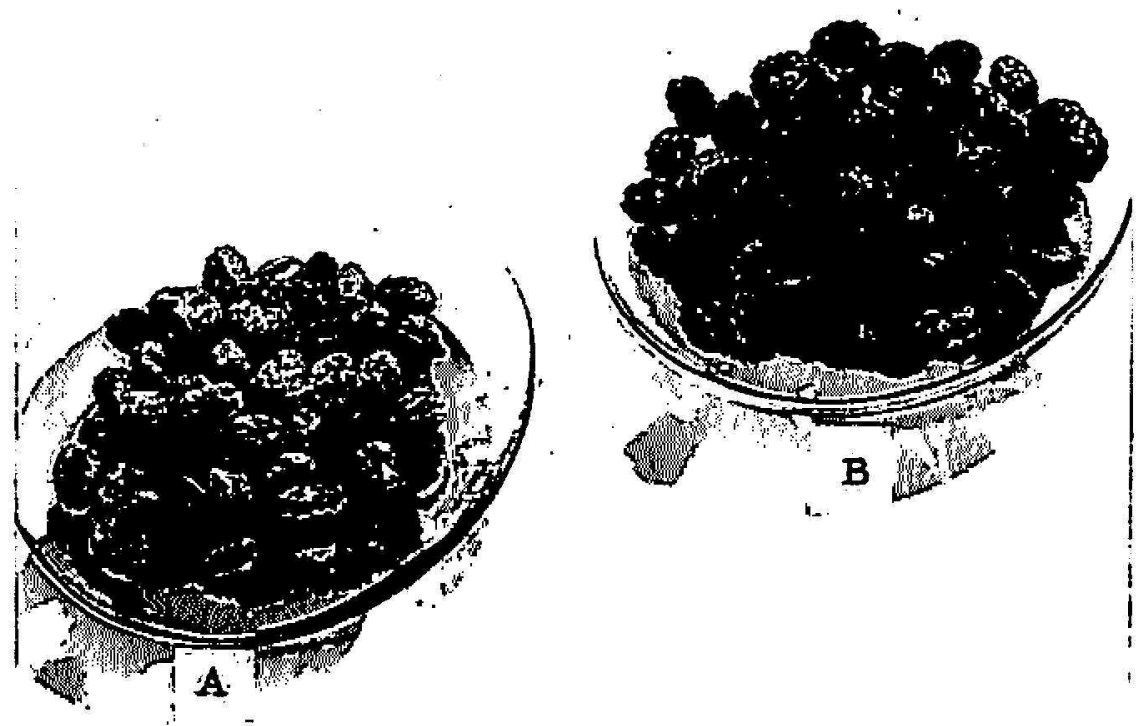

Frg. 1.-A, Papaya seed after treatment with Gibrel, a proprietary containing 0.88 percent of potassium gibberellate; $B$, untreated seed for comparison.

The standard error and least differences required for significance between means are shown below:

\section{Ilem}

Difference between highest and lowest

Difference between highest and 2nd lowest

Difference between highest and $3 \mathrm{~d}$ lowest

Difference between highest and 4th lowest

Standard error of a mean: 0.469 , with 12

$\begin{array}{cc}5 \text { percent } & l \text { percent } \\ 2.11 & 2.73 \\ 1.96 & 2.57 \\ 1.76 & 2.36 \\ 1.44 & 2.02\end{array}$

d.f.

The results obtained show that the treatment of papaya seed with gibberellic acid is not effective in accelerating its germination. No significant differences were found in the germination rate of papaya seed as affected by the different dosages of gibberellic acid.

TABLE 1.-Effect of gibberellic acid on the germination percentage of papaya seed

\begin{tabular}{c|c|c|c|c}
\hline $\begin{array}{c}\text { Dosage } \\
\text { (milligrams) }\end{array}$ & Seed per plot & Seed per treatment & $\begin{array}{c}\text { Mean number of seed } \\
\text { germinated }\end{array}$ & Germination \\
\hline & Number & Number & Number & Percent \\
0 & 15 & 75 & 12.60 & 84.00 \\
2.50 & 15 & 75 & 12.20 & 81.33 \\
5.00 & 15 & 75 & 12.40 & 82.66 \\
7.54 & 15 & 75 & 12.00 & 80.00 \\
10.00 & 15 & 75 & 11.60 & 77.33 \\
\hline
\end{tabular}




\section{EFFECT OF GIBBERELLIC ACID ON THE GEIMINATION \\ PERCENTAGE OF PAPAYA SEED}

The effect of gibberellic acid on the germination percentage is shown in table 1. The standard error and least differences required for significances between means in table 1 are shown in the following tabulation:

\section{$\mathrm{Ilem}$}

Difference between highest and lowest

Difference between highest and 2nd lowest

Difference between highest and $3 d$ lowest

Difference between highest and 4th lowest

Standard error of a mean: 0.966 , with 12

d.f.

$\begin{array}{cc}5 \text { percent } & 1 \text { percent } \\ 4.35 & 5.64 \\ 4.05 & 5.31 \\ 3.64 & 4.86 \\ 2.97 & 4.17\end{array}$

The data show that the dosages of gibberellic acid used had no significant influence on seed germination percentage.

\section{SUMMARY}

Papaya seed were treated with the potassium salt of gibberellic acid to determine the effect on the time interval and percentage of germination. The dosages used were $0,2,4,6$, and 8 ounces of 0.88 percent of potassium gibberellate per 100 pounds of seed.

No significant effect was observed in accelerating the germination of papaya seed nor on the germination percentage.

\section{RESUMEN}

Se trató semilla de papaya con la sal de potasio del ácido giberélico para determinar si era posible acelerar el tiempo normalmente requerido para la germinación, o si éste tenía alguna influencia sobre el porcentaje de su germinación.

Se usaron 5 tratamientos, a saber: $0,2,4,6$ y 8 onzas de giberelato de potasio al 0.88 por ciento por cada 100 libras de semilla.

No se encontró diferencia significativa alguna en cuanto al tiempo de germinación de la semilla como resultado de los tratamientos. Tampoco se encontró diferencia significativa en cuanto al porcentaje de germinación como resultado de los diferentes tratamientos con ácido giberélico.

\section{LITERATURE CITED}

1. Alonso-Olivé, R. E., Observaciones sobre el Cultivo y Mejoramiento del la Fruta Bomba, Bul. 67, Est. Exp. Agr. Santiago de las Vegas, La Habana, Cuba, 1952.

2. Witter, S. H., and Bukovac, M. J., Gibberillin and higher plants: VII Seed treatments for beans, peas, and sweet corn, Mich. State Univ. Agr. Exp. Sta. Quart. Bul. 40(1) 215-24, 1957.

3. Gibrel (Brand Plant Growth Substance) Monograph (1-67 pp.) Merck and Co. Inc., Chem. I)iv., Rahway, N.J. 